\title{
FRESHWATER FISH ASSEMBLAGES IN CYPRUS WITH EMPHASIS ON THE EFFECTS OF DAMS
}

\author{
Stamatis ZOGARIS ${ }^{1 *}$, Yorgos CHATZINIKOLAOU ${ }^{1}$, Nicholas KOUTSIKOS ${ }^{1}$, \\ Alcibiades N. ECONOMOU ${ }^{1}$, Elena OIKONOMOU ${ }^{1}$, Giorgos MICHAELIDES ${ }^{2}$, \\ Eleftherios HADJISTERIKOTIS ${ }^{3}$, William R.C. BEAUMONT ${ }^{4}$, and Maria T. FERREIRA ${ }^{5}$ \\ ${ }^{1}$ Hellenic Center for Marine Research, Anavissos, Greece \\ 2114 Alexandrou Papagou Str., CY-8027, Pafos, Cyprus \\ ${ }^{3}$ Cyprus Ministry of the Interior, CY-1453 Nicosia, Cyprus \\ ${ }^{4}$ Game and Wildlife Conservation Trust, Salmon and Trout Research Centre, The River Laboratory, East Stoke, \\ Wareham Dorset BH20 6BB UK \\ ${ }^{5}$ Departamento de Engenharia Florestal, Instituto Superior de Agronomia, Tapada da Ajuda, \\ 1349-017 Lisbon, Portugal
}

Zogaris S., Chatzinikolaou Y., Koutsikos N., Economou A.N., Oikonomou E., Michaelides G., Hadjisterikotis E., Beaumont W.R.C., Ferreira M.T. 2012. Freshwater fish assemblages in Cyprus with emphasis on the effects of dams. Acta Ichthyol. Piscat. 42 (3): 165-175.

Background. The distribution of freshwater fishes in Cyprus is poorly known. The island is particularly interesting because of its biogeographical isolation and the long-term influence of humans on the biota, especially due to the recent damming of many rivers. This study documents preliminary baseline freshwater fish assemblage patterns including insights on the impact of the dams.

Materials and methods. Site-specific fish presence data were gathered using a backpack electrofishing device, literature reviews and unstructured expert interviews.

Results. A total of 53 aquatic sites in 18 river basins of Cyprus were surveyed, most of which have dam reservoirs along parts of their channels. The survey confirms the existence of sixteen fish species of which 12 are non-indigenous. Native species were found at very few sites, although the European eel was reported to be ubiquitous. Twenty-four sites sustained non-indigenous fish ( $45 \%$ occurrence at all sites, or $60 \%$ at all sites with fish present). Reservoir dams were the most species-rich generic habitats but hosted almost exclusively non-indigenous species. Conclusion. Cyprus' streams are characterized by a scarcity of fishes. The absence of primary- and primary-like native species is attributed to the palaeogeography of the island which has not been connected to the continent since the Messinian Salinity Crisis. At present, only two peripheral (Anguilla anguilla and Salaria fluviatilis) and one secondary (Aphanius fasciatus) native inland fish species are reported. These, along with euryhaline marine transient species suffer from the extensive degradation of natural riverine habitats. Dams influence riverine fish assemblages by degrading downstream aquatic habitats, impeding fish movements, and by providing refuges for non-indigenous fish populations.

Keywords: freshwater fishes, fish communities, non-indigenous species, native species conservation, reservoirs

\section{INTRODUCTION}

Cyprus is an eastern Mediterranean island-state that hosts an estimated 108 dams; it therefore has one of the densest dam reservoir concentrations in the European Union (Anonymous 2006). The majority of dams have been developed in Cyprus in the 1960s and 1980s facilitating extensive river water abstraction, primarily for irrigation (Omorphos et al. 2005). Therefore, most rivers are intersected by dams and have altered natural flow regimes. Moreover, there is a remarkable lack of knowledge of natural flow conditions and aquatic biotic communities before the dam building (Charalambidou and Gücel 2009), including baseline knowledge of the native inland fish fauna (Zogaris et al. 2011).

Taking biogeographic factors first, Cyprus' inland waters have a distinctly insular geological history, being

\footnotetext{
* Correspondence: Stamatis Zogaris MSc, PhD., Hellenic Center for Marine Research, Institute of Marine Biological Resources and Inland Waters, $46,7 \mathrm{~km}$ Athens-Sounio, Mavro Lithari, Anavissos, Attiki, GR-19013 Greece, phone: +30 22910 76393, mobile: +30 693 2000010, e-mail: zogaris@ath.hcmr.gr or zogaris@gmail.com.
} 
located on an island within a semi-arid region. Cyprus arose from the sea due to tectonic changes during the Mesozoic (22 million year ago) and has been isolated from the surrounding mainland with the exception for a short-term connection with the arid Levantine coast of western Asia during the Messinian Salinity Crisis, about 5 million year ago (Böhme and Wiedl 1994, Hadjisterikotis et al. 2000). There is no evidence that Cyprus' rivers ever had river-confluences with basins of the adjacent mainland during this short period when the eastern Mediterranean Sea sea bed resembled a vast saline desert (Baier et al. 2009). However, fossil evidence shows that extensive inland freshwaters did exist on Cyprus during this time (Hadjisterikotis et al. 2000, Kassapis 2011) and we can assume some fish species could have colonized them. Today, Cyprus' inland freshwater fish fauna is known to comprise solely of three native inland water fishes, namely, only two peripheral: European eel, Anguilla anguilla (L.) and freshwater blenny, Salaria fluviatilis (Asso, 1801) and one secondary: Mediterranean toothcarp, Aphanius fasciatus (Valenciennes, 1821) (see Bianco et al. 1996, Kottelat and Freyhof 2007). Euryhaline marine fish such as mugilids are also known to enter inland waters locally. It is not known if the depauperate freshwater fish fauna of Cyprus is solely a result of biogeographic isolation or related to extended periods of local aridity, and/or recent anthropogenic habitat degradation.

There is no doubt that humans have greatly altered aquatic environments on Cyprus for hundreds of years. Cyprus' inland waters currently host several non-indigenous fish (Anonymous 1998) introduced recently by humans, but specific distributions of most of these are very poorly recorded (Elvira 2001, Froese and Pauly 2012). One of the most important biodiversity conservation issues facing Cyprus concerns the ecological integrity of its inland waters; and building fundamental knowledge baselines utilizing fish is now a policy-relevant imperative (Anonymous 2000).

We surveyed fish assemblages in various inland water bodies in Cyprus, particularly focusing on basins with perennial streams and dams, especially in the more humid western part of the island. Our aim here is to provide the island's first description of current freshwater fish distribution patterns, and to explore the effects of the many dams on the fish assemblage composition.

\section{MATERIALS AND METHODS}

We conducted the first broad-scale survey of freshwater fish in Cyprus (Fig. 1, Table 1) using both site-based electrofishing, expert interviews, and a literature search during the spring/summer periods of 2009, 2010, and spring of 2011. Two backpack electro-fishers (Bulgarian custom-made unit, 700 v. and a Smith-Root L24 980 v.) were used to collect fish presence/absence data. Sampling site selection was based on aquatic feature representativeness and accessibility. The fish recording technique followed a rapid search-find procedure where stream site fish were collected by a two- or three-person team in a procedure similar to standard river fish sampling protocol (Anonymous 2004). Only one sampling run was conducted at each site and the longitudinal distance usually covered was at least $30 \mathrm{~m}$ of river stretch. All wadable habitats were carefully sampled for fish and if no fish were found sampling usually continued for at least $120 \mathrm{~m}$ of the river stretch. The size of sampling area varied with the stream size and local accessibility. At some sampling locations inaccessibility or lack of water forced the research team to sample less than the standard $100 \mathrm{~m}$ length; but $30 \mathrm{~m}$ was the bare minimum. All fish specimens were immediately released once numbers and size classes of each species were recorded. Habitat features were carefully recorded at each site; categorizing each sampling site by dominant generic habitat type.

To complement electrofishing, a species presenceabsence review was conducted through the available grey literature and through interviews with knowledgeable local researchers (see acknowledgements). Expert naturalists and professional biologists reviewed all the sites that were visited during sampling and provided data on presenceabsence of species. Obviously, wherever ambiguous or questionable anecdotal information existed, the interview responses are ignored; and, we clearly state data acquisition method for each species record in each site.

Relative degradation pressures imposed by the proximity of dams, situated upstream and/or downstream of the researched sampling sites were provisionally assessed by expressing the distance of each sampling site to a dam or major water obstruction (i.e., the irrigation reservoir or water diversion structure). An arbitrary scaling assessment is applied in order to outline conspicuous fish distribution attributes relative to the positions of the dams in the longitudinal river dimension. In this way, a 5-point scale pressure categorization was implemented as follows: $1=$ no dam present upstream or downstream of sampling site; 2 = dam at least 10 river $\mathrm{km}$ away from sampling site; $3=$ dam $5 \mathrm{~km}$ to $10 \mathrm{~km}$ away; $4=$ dam less than $5 \mathrm{~km} ; 5$ = site located at or within dam's reservoir. This simple dam distance gradient relative to the position of the dams may assist in interpreting general fish distribution

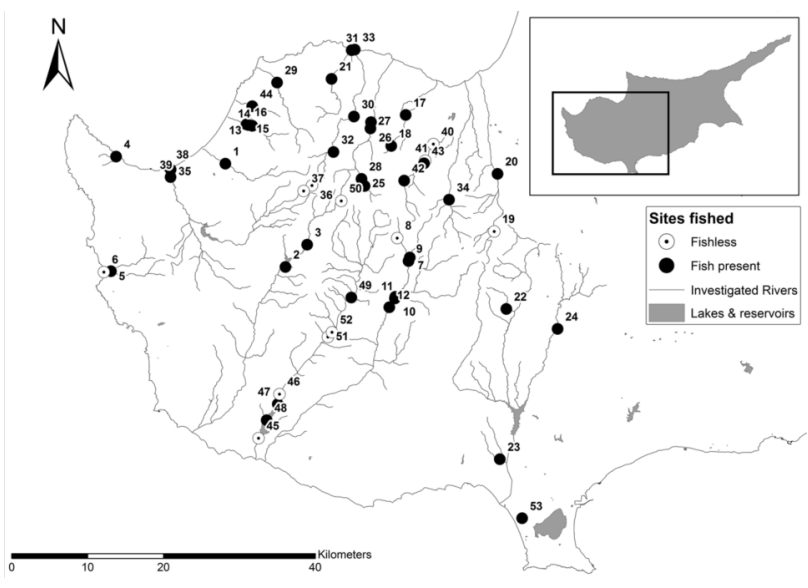

Fig. 1. Investigated sites and rivers in the western part of Cyprus (see Table 1) 
Table 1

Detailed characteristics of individual sampling sites

\begin{tabular}{|c|c|c|c|c|c|c|c|c|}
\hline $\begin{array}{l}\dot{0} \\
Z \\
\stackrel{\Xi}{*}\end{array}$ & Site name & $\underset{\text { GIS }}{\text { coordinate X }}$ & $\begin{array}{c}\text { GIS } \\
\text { coordinate Y }\end{array}$ & $\frac{\sqrt{n}}{i !}$ & 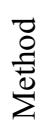 & $\frac{n}{2}$ & 商 & Basin \\
\hline 1 & Fragma Argaka & 454560.52 & 3878525.29 & 1 & 2 & 5 & 5 & Makounta \\
\hline 2 & Fragma Kannaviou & 462490.65 & 3864912.93 & 1 & 2 & 5 & 5 & Ezousa \\
\hline 3 & Panagia Diakou Agia & 465351.69 & 3867856.10 & 1 & 1 & 1 & 3 & Ezousa \\
\hline 4 & Aphrodites baths & 440161.74 & 3879471.00 & 1 & 3 & 1 & 1 & Agios Ioannis \\
\hline 5 & Avakas & 439479.86 & 3864356.37 & 1 & 1 & 1 & 1 & Avgas \\
\hline 6 & Avakas Mouth & 438542.67 & 3864247.85 & 0 & 2 & 1 & 1 & Avgas \\
\hline 7 & Agios Avvakoum & 478886.68 & 3866158.68 & 1 & 1 & 1 & 2 & Diarizos \\
\hline 8 & Milikouri Spring & 477228.42 & 3868733.36 & 0 & 2 & 1 & 2 & Diarizos \\
\hline 9 & Pareklissoudi & 478716.13 & 3865697.33 & 1 & 1 & 1 & 2 & Diarizos \\
\hline 10 & Us Gef Kelefou & 476960.13 & 3860969.25 & 1 & 1 & 1 & 4 & Diarizos \\
\hline 11 & Ds Gef Kelefou & 476924.72 & 3860767.23 & 1 & 1 & 1 & 4 & Diarizos \\
\hline 12 & Fragma Arminou & 476924.72 & 3860767.23 & 1 & 1 & 5 & 5 & Diarizos \\
\hline 13 & Gialia Seep Pond & 457738.80 & 3883704.35 & 0 & 1 & 1 & 1 & Gialia \\
\hline 14 & Gialia Us Spring & 458113.43 & 3883520.98 & 1 & 1 & 1 & 1 & Gialia \\
\hline 15 & Gialia Spring & 457616.55 & 3883626.42 & 1 & 1 & 1 & 1 & Gialia \\
\hline 16 & Gialia Ds spring & 457354.51 & 3883709.65 & 1 & 1 & 1 & 1 & Gialia \\
\hline 17 & Fragma Galinis & 478453.04 & 3885114.12 & 1 & 4 & 5 & 5 & Kampos \\
\hline 18 & Kampos 1 & 476441.38 & 3880873.97 & 1 & 1 & 1 & 1 & Kampos \\
\hline 19 & Us fishfarm Kargotis & 490010.14 & 3869600.61 & 0 & 1 & 1 & 1 & Kargotis \\
\hline 20 & Gef Evrychou & 490445.95 & 3877193.73 & 1 & 1 & 1 & 1 & Kargotis \\
\hline 21 & Fragma Katouri & 468565.96 & 3889715.91 & 1 & 4 & 5 & 5 & Katouris \\
\hline 22 & Mesa potamos Kouri & 491613.06 & 3859368.56 & 1 & 1 & 1 & 2 & Kouris \\
\hline 23 & Frag Kantou & 490749.67 & 3839562.52 & 1 & 2 & 5 & 5 & Kouris \\
\hline 24 & AgMamas Limnatis & 498364.06 & 3856743.97 & 1 & 1 & 1 & 2 & Kouris \\
\hline 25 & Fragma Tsakistras & 472920.28 & 3875592.39 & 1 & 2 & 5 & 5 & Limnitis \\
\hline 26 & Kat Gef Limniti & 473771.90 & 3884006.11 & 1 & 1 & 2 & 1 & Limnitis \\
\hline 27 & Gef Limniti & 473685.56 & 3883173.89 & 1 & 2 & 2 & 1 & Limnitis \\
\hline 28 & Gef Mavres Sykies & 472510.41 & 3876528.71 & 1 & 1 & 4 & 1 & Limnitis \\
\hline 29 & Fragma Pomou & 461396.48 & 3889063.57 & 1 & 3 & 5 & 5 & Livadi \\
\hline 30 & Pirgos 1 & 471519.54 & 3884741.94 & 1 & 1 & 1 & 1 & Pyrgos \\
\hline 31 & Kato Pirgos & 471217.59 & 3893488.52 & 1 & 2 & 1 & 1 & Katouris \\
\hline 32 & Vrondisia & 468827.41 & 3880069.30 & 1 & 1 & 1 & 1 & Pyrgos \\
\hline 33 & Ekv PlatisPyrgoy & 471624.33 & 3893566.73 & 1 & 1 & 1 & 1 & Pyrgos \\
\hline 34 & Fragma Kalopanagioti & 484093.85 & 3873586.74 & 1 & 3 & 5 & 5 & Marathasa \\
\hline 35 & Polis Crys 1 & 447357.37 & 3877754.73 & 1 & 1 & 2 & 1 & Chrysochou \\
\hline 36 & Stavros kat camping & 465988.66 & 3875664.23 & 0 & 2 & 1 & 2 & Chrysochou \\
\hline 37 & Stavros Psokas 1 & 464880.05 & 3874947.44 & 0 & 2 & 1 & 2 & Chrysochou \\
\hline 38 & Polis Mouth 1 & 447060.07 & 3878118.45 & 1 & 1 & 2 & 1 & Chrysochou \\
\hline 39 & Polis Mouth 2 & 447341.80 & 3876761.21 & 1 & 1 & 2 & 1 & Chrysochou \\
\hline 40 & Gef Xerou Lefkas & 481985.53 & 3881119.62 & 0 & 2 & 4 & 4 & Xeros(Lefkas) \\
\hline 41 & Kat Fragma Kafiziedes & 480818.84 & 3878699.20 & 0 & 1 & 4 & 3 & Xeros(Lefkas) \\
\hline 42 & Fragma Kamenou Paidiou & 478140.95 & 3876296.33 & 1 & 4 & 5 & 5 & Xeros(Lefkas) \\
\hline 43 & Fragma Kafizides & 480731.40 & 3878542.41 & 1 & 2 & 5 & 5 & Xeros(Lefkas) \\
\hline
\end{tabular}


Table 1 (cont.)

\begin{tabular}{|c|c|c|c|c|c|c|c|c|}
\hline $\begin{array}{l}\dot{0} \\
Z \\
\stackrel{0}{0}\end{array}$ & Site name & $\begin{array}{c}\text { GIS } \\
\text { coordinate } X\end{array}$ & $\begin{array}{c}\text { GIS } \\
\text { coordinate Y }\end{array}$ & : & $\begin{array}{l}\vec{D} \\
\stackrel{0}{0} \\
\sum\end{array}$ & $\begin{array}{l}n \\
\stackrel{2}{D} \\
0\end{array}$ & 命 & Basin \\
\hline 44 & Fragma Ag Marina & 458112.45 & 3886098.90 & 1 & 2 & 5 & 5 & $\begin{array}{l}\text { Xeros } \\
\text { (Ag. Marina) }\end{array}$ \\
\hline 45 & Asprokremma Ponds & 458939.57 & 3842342.04 & 0 & 1 & 4 & 1 & Xeros(Pafos) \\
\hline 46 & Gef Choletria & 461696.22 & 3848151.80 & 0 & 1 & 1 & 4 & Xeros(Pafos) \\
\hline 47 & Finikas $\mathrm{d} / \mathrm{s}$ prodam & 461476.01 & 3846841.79 & 1 & 1 & 4 & 4 & Xeros(Pafos) \\
\hline 48 & Frag Asprokremmou & 458939.57 & 3842342.04 & 1 & 1 & 5 & 5 & Xeros(Pafos) \\
\hline 49 & Gef Roudias & 471289.42 & 3860966.64 & 1 & 1 & 1 & 2 & Xeros(Pafos) \\
\hline 50 & Spring Dixaloi & 469843.51 & 3873628.34 & 0 & 2 & 1 & 2 & Ezousa \\
\hline 51 & Gef Salamiou Xeros & 468081.17 & 3855699.27 & 0 & 1 & 1 & 2 & Xeros(Pafos) \\
\hline 52 & Perasma Xeros & 468626.36 & 3856313.56 & 0 & 1 & 1 & 2 & Xeros(Pafos) \\
\hline 53 & Alyki Akrotiri & 495655.08 & 3830566.91 & 1 & 3 & 1 & 1 & Kouris \\
\hline
\end{tabular}

Site No.- - as presented on map in Fig. 1; Site name - the arbitrary name proposed by authors; Fish presence codes: $0=$ no fish; 1 = fish confirmed; Method-data acquisition method (in progressively decreasing reliability of data): $1=$ Electrofishing, 2 = visual observation at site and/or expert interview, $3=$ expert documentation and/or literature, $4=$ literature documentation; DPUS $=$ dam proximity upstream, DPDS $=$ dam proximity downstream; Dam proximity codes: $1=$ no dam present upstream of sampling site, $2=$ dam at least 10 river $\mathrm{km} ; 3=$ dam $5 \mathrm{~km}$ to $10 \mathrm{~km} ; 4=$ dam less than $5 \mathrm{~km} ; 5=$ site located at or within dam reservoir; Basin $=$ site's watershed name.

patterns in relation to dams. All data were entered into a simple relational database supported by GIS site locations. SPSS 13.0 for Windows software and Primer (Ver. $6)$ software were used for statistical analysis for the presentation of relevant data.

\section{RESULTS AND DISCUSSION}

Species-richness: non-indigenous versus native. In total, 18 river basins were researched and ichthyological information was acquired from 53 sites; however only 35 sites were electrofished. Fourteen species of fish were collected during electrofishing, while another two taxa are confirmed in the grey literature review and/or through the expert interviews and field observations with respect to the specific inspected sites (Table 2). Of this list, two taxa remain unidentified to species level, a grey-mullet species (Mugilidae; reported by local experts at Chrysochou and Akrotiri) and a species of tilapia (Oreochromis sp.; recorded by local experts at Asprokremmos Reservoir and observed from shore at an adjacent artificial channel). Collectively, evidence regarding fish presence was recorded in 40 surveyed sites (75\% of surveyed sites) (Fig. 1, Table 1). The average number of species per site was $1.9 \pm 2.04 \mathrm{SD}$ (range: 0-8). Dam type sites had an average of $4.2 \pm 2.49$ SD species (Fig. 2). By international standards Cyprus' stream site species-richness is considered very low for stream fish faunas, although, worldwide, islands are known to have very restricted numbers of freshwater fish (Bianco et al. 1996, Mathews 1998).

Twenty-four surveyed sites had non-indigenous fish (45\% occurrence in all sites). Evidence for native fish presence was gathered at 28 sites (53\% occurrence); nearly all of these sites were reported to host European eel
(Anguilla anguilla), the most widespread native fish by far (51\% occurrence). However, if we do not consider information from the interviews and the scant literature, the observed occurrence of native fish is surprisingly low. Eels were collected/observed at only four sites in three river systems, flathead grey mullet, Mugil cephalus L., were found at one river-mouth site, and the only other inland fish, Mediterranean toothcarp, Aphanius fasciatus, was found at only one lagunal site.

Species assemblages and inland water typology. A cluster analysis of sites with confirmed and documented fish presence $(n=40)$ clearly separates fish assemblages between reservoir and non-reservoir groups (cutoff of approximately $20 \%$ similarity) (Fig. 2). Within the non-reservoir group there are distinctive cold-water rainbow trout, Oncorhynchus mykiss (Walbaum, 1792), and brown trout, Salmo trutta L., groups, and a large eel-only cluster. The reservoirs show a heterogeneous array of assemblages among them, eel-only sites are obviously more similar to each other, while the trout-dominated sites are only slightly more similar to each other than the reservoir sites. Perhaps the remarkably low number of river-mouth or coastal wetland fish assemblages is a result of anthropogenic degradation in the river's connectivity to the sea (due to extensive water abstraction upstream of the river mouths).

The survey inspected sites belonging to nine generic habitat types (Fig. 3). The reservoir, perennial stream, and coastal lagoon generic habitat types have the majority of fish species (Fig. 4). The eel and rainbow trout are most widespread in a variety of habitats and sites; while eastern mosquitofish, Gambusia holbrooki Girard, 1859, and roach, Rutilus rutilus (L.), are the next most frequent and 


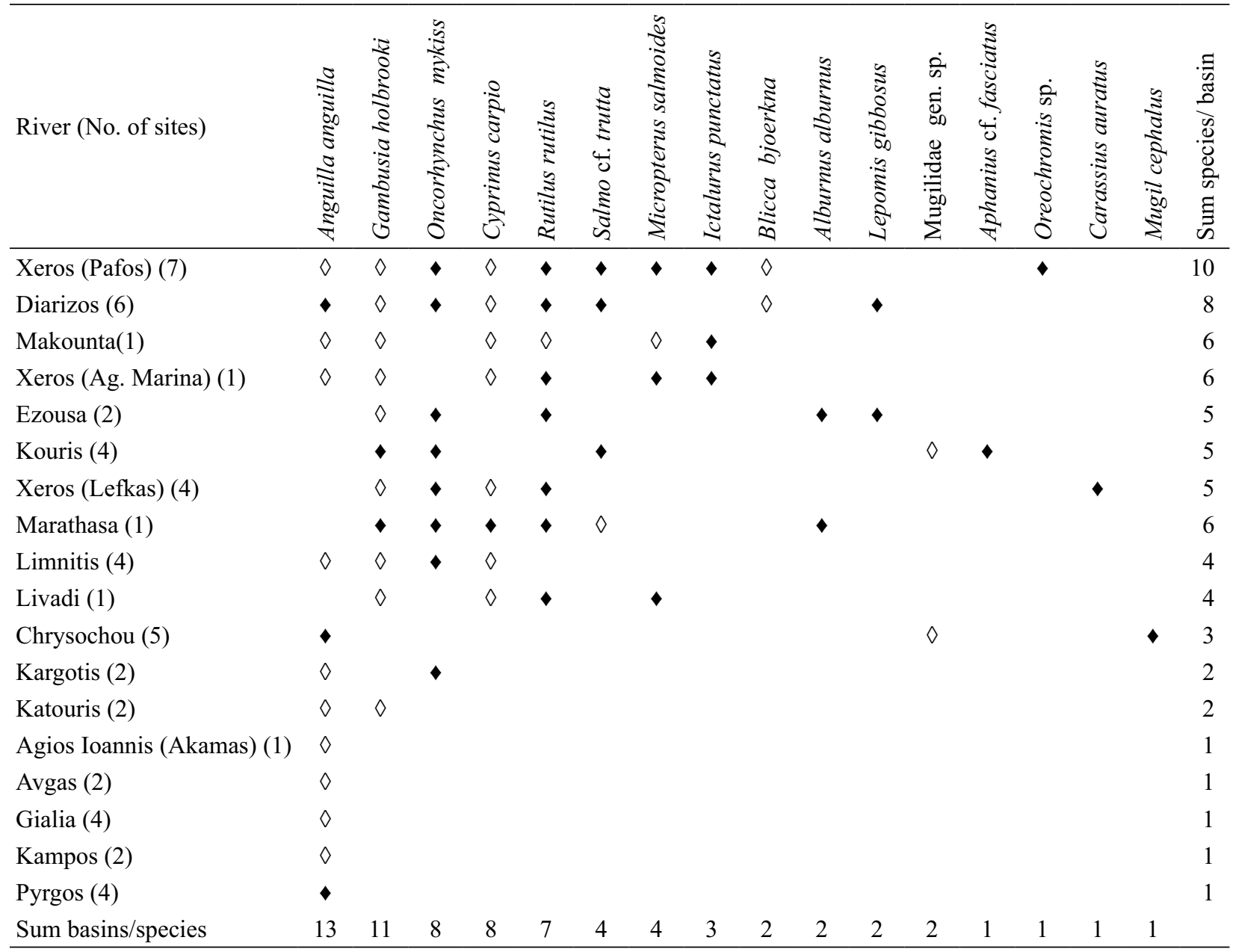

$\diamond$ published- and unpublished sources, field observations.

widespread in a variety of habitat types (Fig. 4). The majority of species are located within the dam reservoirs or very close to them, especially those fishes typifying the reservoir lacustrine community. Typical lacustrine species are scarce beyond more than $5 \mathrm{~km}$ upstream or downstream of reservoirs (Fig. 5).

Several of the surveyed sites showed obvious hydromorphologically degraded conditions and although reference conditions cannot be documented, evidence for extensive recent anthropogenic changes in water surface conditions is widespread. Signs of severe waters stress are common in the lowland and mid-sections of rivers, as indicated by excessive anthropogenic abstraction that has lowered dry-season water levels and stream flow (see Zogaris et al. 2011). Several streams reported as being perennial flowing in the past were found to be in artificially intermittent state, where only pools and desiccated river beds were left behind by early summer, presumably due to anthropogenic overexploitation as is prevalent in many eastern Mediterranean rivers (Skoulikidis et al. 2011). Circumstantial observations provide evidence that anthropogenic obstacles impacting river connectivity such as weirs and flow-meters frequently impede native fish dispersion through river drainage networks; and this may stall non-indigenous fish species dispersal also. However, another reason for less surface water in streams and generally poorer fish habitats in Cyprus in recent years may also be related to recent climatic change phenomena. Since 1970 there has been a notable decrease in precipitation (Klohn, unpublished*), and several prolonged desiccating droughts have occurred (Michaelides and Pashiardis 2008). The combined pressures of widespread water retention in dams, river water transfers, obstacles to fish-movements, surface water over-exploitation, pollution and decreasing precipitation seem to have had a broad-scale impact on lotic ecosystems during the last three decades.

Native species. Freshwater fish are scarce in the streams of western Cyprus, and interviews with experts suggest that nearly all native fish have contracted their present-day distributions in recent decades, especially the eel. The presence of eel was not easily detected in our survey often due to difficulties in capturing this cryptic fish under conditions which were adverse for electrofishing.

\footnotetext{
${ }^{*}$ Klohn W. 2002. Reassessment of the island's water resources and demand of the island of Cyprus. Synthesis report. Water Development Department (WDD) and Food and Agriculture Organization of the United Nations (FAO), Ministry of Agriculture, Natural Resources and Environment, Nicosia, Cyprus.
} 


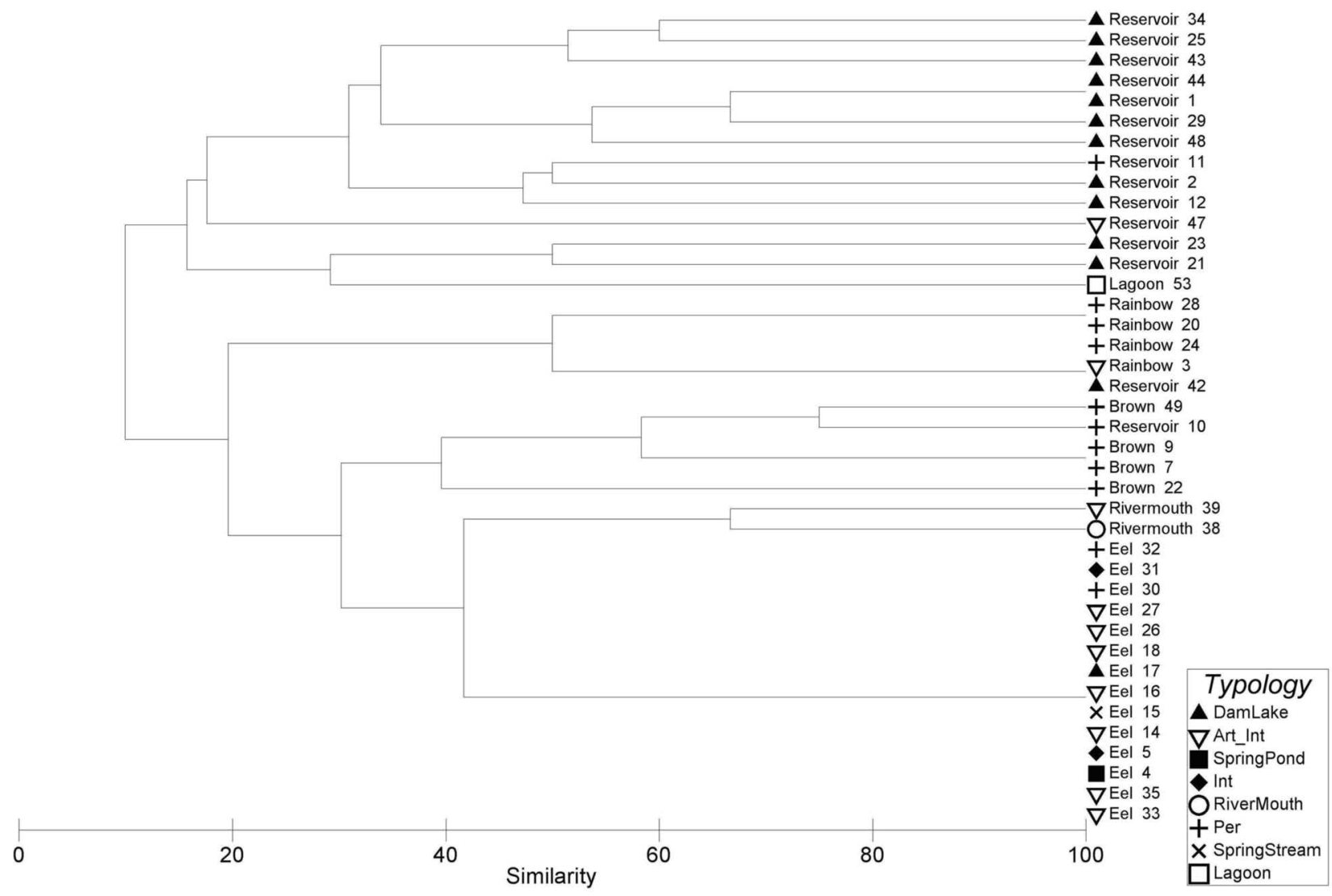

Fig. 2. Cluster analysis dendrogram using Jaccard coefficient of similarity classifying sites $(n=40)$ based on species assemblage similarity; Each site is presented with respect to its generic habitat type, the dominant assemblage identity as defined in this analysis and the specific site numerical location mapped on Fig. 1; Codes: Eel = sites dominated by Anguilla anguilla; Rivermouth = sites dominated by marine euryhaline species; Rainbow $=$ sites dominated by Oncorhynchus mykiss; Brown = sites dominated by Salmo trutta; Reservoir = sites dominated by lacustrine fishes; Lagoon $=$ hypersaline coastal wetlands

Eel capture with electricity was sometimes impeded by locally high conductivity waters, low water-levels potentially forcing eels to move to summer refugia, and habitat constraints such boulder-strewn substrates or reed beds. However, 13 of the 18 stream basins studied in this survey were reported to have eels. This may not, however, reflect the current state of eel distribution in western Cyprus. Twelve of the river basins investigated have high irrigation dams that probably block eel passage to the
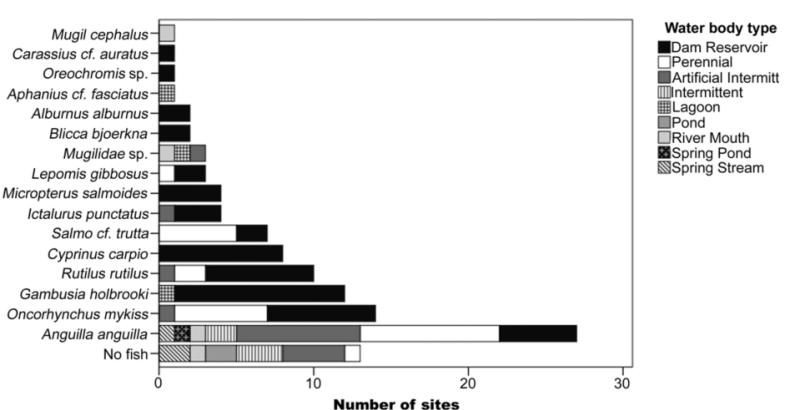

Fig. 3. The relative frequency of occurrence of fish species (presence in number of sites) in relation to the water body type respective stream's upland sections. The majority of streams are effectively starved of their downstream summer flows due to water diversions for irrigation. As a result many lowland wetland and summer-refuge instream habitats have largely become unsuitable for eel survival. Obviously, many anthropogenic obstructions to eel movement become more permanent during long periods of drought. In fact, only two locations were detected where a stream had an open flowing outfall to the sea during early summer; and these coincided with the only locations where "glass eels" were recorded by us on the island. Moreover, this connectivity degradation is corroborated by the fact that fish species of marine origin (e.g., the Mugilidae) currently have an extremely restricted distribution in Cyprus' inland waters.

From a conservation standpoint, a mystery surrounds the low species richness of native freshwater fish. There are very few ways that Cyprus could be colonized/re-colonized by freshwater fish although it was connected to the Asian mainland for a relatively short period - during the Messinian Salinity Crisis (approximately 5.59-5.33 million years ago) (Baier et al. 2009). Apart from formerly euryhaline species or diadromous migration by salt-toler- 
ant species (i.e., potentially salmonids during the glacial periods) only species that could be transported by man or other animals may have reached the island. The ancestor of the freshwater blenny (Salaria fluviatilis) for example, is said to have been a euryhaline species, allowing incursions into fresh water and subsequent dispersal via the sea (Almada et al. 2009). However the freshwater blenny on Cyprus is not reported in any recent survey (Bath 2003) and is not known by the island's ichthyologists. This species is extremely vulnerable to habitat degradation and longitudinal river connectivity changes (Côtè et al. 1999, Benejam et al. 2010) and may now be extremely rare on the island, if it still exists. Obviously the extinction pressure on semi-arid islands is heightened within restricted aquatic habitats, especially where only rather small isolated river basins exist, such as on Cyprus (Adams and Warren 2005). If Cyprus ever had native freshwater fish species it is nearly certain that they may have been lost due to increased aridity events or a combination of climat-

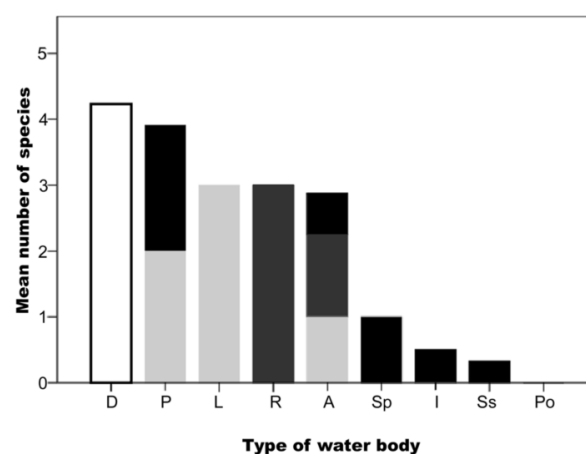

Fig. 4. Mean number of species found at 53 sites in Cyprus related to the proximity of dams upstream of site (dam $\mathrm{u} / \mathrm{s})$. On $\mathrm{x}$-axis generic habitat types are given as: $\mathrm{D}=$ dam reservoir, $\mathrm{P}=$ perennial, $\mathrm{L}=$ lagoon, $\mathrm{R}=$ river mouth, $\mathrm{A}=$ artificial intermittent, $\mathrm{Sp}=$ spring pond, $\mathrm{I}=$ intermittent, $\mathrm{Ss}=$ spring stream, $\mathrm{Po}=$ pond.

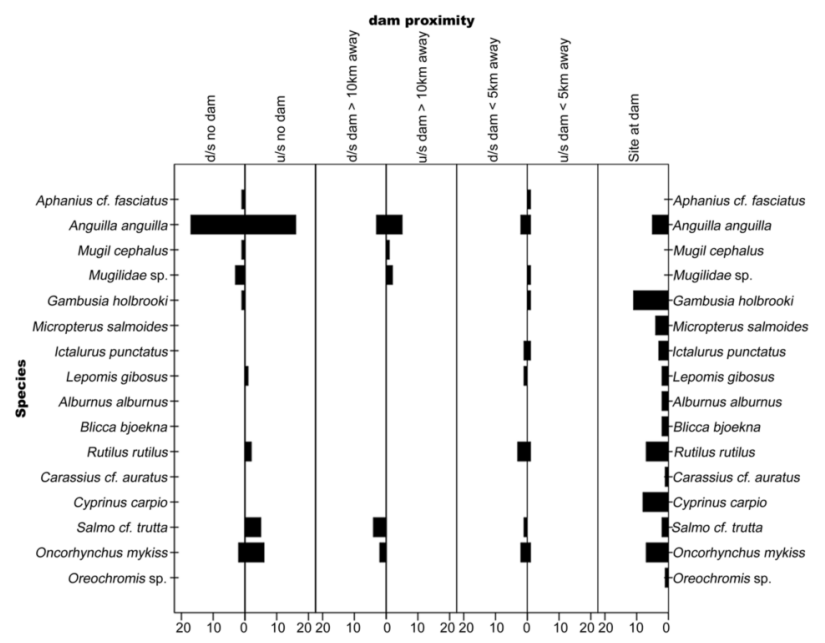

Fig. 5. The frequency of occurrence of fish species at individual sites $(n=53)$ in relation to the dam proximity (upstream and downstream); The $x$ axis of this plot shows the number of sites where a species was recorded either upstream $(\mathrm{u} / \mathrm{s})$ or downstream $(\mathrm{d} / \mathrm{s})$ of a dam ic and anthropogenic pressures (Davis et al. 1998, Hadjisterikotis et al. 2000).

Non-indigenous species. Our initial survey shows that several non-indigenous fishes maintain self-sustaining populations in reservoirs and locally in the related adjacent water bodies, immediately upstream or downstream of dams. Many of these species were allegedly introduced accidentally. A fairly common accidental means by which non-indigenous fishes are introduced is when species, most frequently cyprinids, are inadvertently transported with the juveniles of common carp, Cyprinus carpio L., (see Welcomme 1988). It has been documented that at least the bleak, Alburnus alburnus (L.), (see Welcomme 1988, Lever 1990) and white bream, Blicca bjoerkna (L.), (see Elvira 2001) have reached Cyprus in this way. Fish have also been indiscriminately and intentionally dispersed by humans in the dams of Cyprus, primarily for recreational angling, and it was stated by experts that there is very poor control over these private introductions. Furthermore, a state-run fish hatchery does exist on the island and it has propagated several species on an exploratory and experimental basis.

Some naturalized non-indigenous populations, especially the trout are of special interest because Cyprus does have rather substantial cold-water stream reaches in its southern mountain range and these would maintain selfsustaining trout populations in the adjacent Eurasian mainland. The presence of brown trout on the island is attributed to an introduction of continental Salmo trutta by R.R. Waterer (Conservator of Forests, 1937-1950) in the mid 1940s; and this was considered an important accomplishment of the British colonial government's forest conservation campaign (Thirgood 1987). During the present investigation we compiled evidence of reproducing brown trout in the upper Kouris River, this being the first documentation of wild salmonid reproduction on the island in recent times (several fry with size ranges 50-55 $\mathrm{mm}$ TL where found in early May 2011). We have no knowledge of the potential for the existence of native brown trout on Cyprus in the distant past, although native trout does exist in several other Mediterranean islands such as Corsica, Sardinia, and Sicily (Kottelat and Freyhof 2007), and may have existed until medieval times on Crete (Rackham and Moody 1996). Furthermore, genetic investigations have never been made to explore the specific provenance of Cyprus' trout populations, and this would be important for a conservation assessment (Laikre 1999).

Non-indigenous species are potentially harmful to native biota, and this has been confirmed with fish in inland waters in many Mediterranean climate-areas (Moyle and Light 1996, Smith and Darwall 2006). However, the degree of impact of non-indigenous fish on aquatic system biota still garners controversy with respect to assessing specific environmental impacts of fish introductions (Godinho and Ferreira 1998, Gherardi and Böhme 2000, Copp et al. 2005). It should be said that some long-established "naturalized non-indigenous 
species", such as the brown trout in the case of Cyprus, might fill a "vacant niche" that may have belonged to a salmonid species that has become extinct in the distant past. Although the idea of niche vacancy in terms of documenting "benign effects" of introduced species has been debated (Herbold and Moyle1986), it has been recently stated that some non-indigenous species do act as functional substitutes for extinct taxa, so in this case nonindigenous species can even be of benefit to insular aquatic ecosystems (Schlaepfer et al. 2011). In this respect, humans may act as vehicles for introducing or "re-introducing" ecological guilds that may evolve to have selfsustaining populations in streams that may have had ecologically equivalent fish species in the past. We must not forget that humans have successfully transported several reptiles, birds and mammals to many Mediterranean islands for centuries and some of these naturalized populations are now legally protected and considered "native" (Gherardi and Böhme 2000, Baier et al. 2009). Humans have also transported live fish throughout much of the Mediterranean in the past; for example common carp and the north African catfish, Clarias gariepinus (Burchell, 1822), have been found in Greco-Roman remains on Cyprus also (Van Neer et al. 2004). Obviously we cannot underestimate the threats non-indigenous fish species can cause; however, a new paradigm seems to be emerging with respect to how we assess the "aliens" place in Mediterranean and European aquatic ecosystems (Gherardi and Böhme 2000, Copp et al. 2005). How we interpret a naturalized species place in the largely anthropogenically-modified Mediterranean landscapes obviously influences conservation and management implications as well (Botkin 2001, Grove and Rackham 2001).

Conservation implications. Until now there has been scant documentation of fish distributions in Cyprus, even for reservoir waters where a recreational angling fishery has been thriving (Stephanou 1988) or within EU Water Framework Directive monitoring demands (Anonymous 2000, Bernez et al. 2002). Very little work has been done on stream fishes in semi-arid insular areas in the Mediterranean, especially compared to temperate river environments (Mathews 1998). Obviously important gaps in baseline knowledge persist on Cyprus and the present survey is necessarily a descriptive pioneering account. Important conservation research needs are however apparent.

Our work provides evidence of the influence of dams and the associated water management on fish assemblages in Cyprus. Dams have definitely affected fish populations, both native and introduced species, since irrigation dam reservoirs may seasonally starve downstream reaches creating artificially intermittent conditions that may contribute to the local range-constriction and extirpation of fishes. Even formerly widespread catadromous species such as the eel seem to have probably declined in Cyprus - perhaps also a reflection of a global decline of this species (Freyhof and Kottelat 2008). It is well known that dams may disrupt the river gradient and block upstream fish migration (Reyes-Gavilán et al. 1996) and thus subsequently affect natural zonation of fish faunas in river systems, and this has been observed in particularly pronounced ways on islands (Chang et al. 1999). In our survey we found that reservoirs host the richest species diversity and a varied lacustrine fish community. Since dams maintain lentic waters in upland areas that may never have had such water features, their non-indigenous fishes could potentially invade and infest upstream areas; these negative effects are well documented in other Mediterranean regions (Godinho and Ferreira 1998, Vinyoles et al. 2007).

In contrast, dams and reservoirs may also function as potential refuges for some native aquatic biota-especially in arid climates; although we did not document evidence of this in terms of the Cypriot ichthyofauna in our survey. The outstanding ornithological importance of certain artificial reservoirs in Cyprus (Charalambidou et al. 2008) indicates that they may be able to provide important refuges for native biodiversity and this situation seems to be confirmed in other Mediterranean islands and in reservoirs of the Middle East's arid lands as well (Evans 1994, Tourenq and Shuriqi 2010).

It would be important to determine if fish could be of interest for monitoring the ecological integrity of streams and reservoirs in Cyprus (Irz et al. 2006, Sabater and Tockner 2010) especially because it is well known that in semi-arid environments surface water bodies are "keystone ecosystems" in the landscape (deMaynadier and Hunter 1997). Even non-indigenous species are known to give important information for assessment and monitoring (Vila-Gispert et al. 2002) and there is a rise in the use of non-indigenous taxa within indices in several European countries (Vandekerkhove and Cardoso 2010).

The inland waters of Cyprus have many distinctive qualities and need careful conservation-relevant research. Recently, Abell et al. (2008) placed Cyprus within the Southern Anatolian Freshwater Ecoregion, yet in contrast to Anatolia, Cyprus has a remarkably depauperate fish and amphibian fauna (only three species of amphibians) and there is mounting evidence that one of its amphibians is a distinct endemic species (Baier et al. 2009). We suspect that ecoregional delineations in parts of the Middle East may need careful re-assessment, especially since biotic distributions of freshwater species are severely lacking as is the case in parts of the Balkans (Zogaris et al. 2009). Cyprus' inland aquatic biotic assemblages and its particular biogeographic identity should be further researched. Perhaps the island has a degree of biological distinctiveness, geological isolation and areal extent to comprise its own freshwater ecoregion.

Conclusion and recommendations. This preliminary survey reveals remarkable gaps in current knowledge on fish distributions in Cyprus; the impact of dams on the island's aquatic biota is especially poorly studied. Part of the reason for a lack of scientific study is the depauperate native fish fauna in Cyprus' inland waters. Furthermore, until recently there was presumably very little interest in non-indigenous species. Cyprus is unusual since it main- 
tains approximately108 dams; and for its area, this represents one of the highest densities of dams in the European Union (Anonymous 2006). This remarkable situation within a semi-arid climate zone makes the use of biotic elements, such as fish especially interesting as a focal element for ecosystem studies, river monitoring and conservation management (Ferreira et al. 2007).

This survey and review of Cyprus' inland fishes indicates that there is substantial value in carefully recording fish distributions on the island. Fishes are potential indicators of surface water ecosystem integrity, they play an important role in local food webs, and non-indigenous fish certainly may impact native biodiversity. Understanding biodiversity patterns is a central issue for conservation scientists and water managers, especially in an environment with extreme water stress (Henrichs and Alcamo 2001). Integrated conservation research approaches are needed to best inform river basin management in the face of competing demands for water use across Cyprus. With respect to inland waters fish conservation, specific research should focus on the following: a) assessing environmental flow requirements below dams and surpassing barriers to stream connectivity, where native fish exist; b) attention to certain focal native species such as European eel, Mediterranean toothcarp, and freshwater blenny and associated habitat requirements; c) utilization of fish as biological quality indicators in order to monitor and restore natural river conditions; and, d) monitoring of non-indigenous fish and their impacts on aquatic systems.

\section{ACKNOWLEDGEMENTS}

We thank all individuals who provided interviews on fish presence, particularly Gerald Dörflinger (Water Development Department), Ioulianos Pantelides, Kostas Moustakas, Marina Argyrou, and Socrates Eugeniou (Department of Fisheries and Marine Research). Andreas Dimitropoulos (Cyprus Wildlife Society), Minas Papadopoulos and Haris Nikolaou (Cyprus Forestry Department), Salih Gücel, Felix Baier, Kostas Kadis (Frederick University), Aris Vidalis and Elli Tzirkalli were especially helpful in initial field work and local organization. This venture was partially initiated by a consulting project executed for the Water Development Department of the Republic of Cyprus. The 2009 and 2010 survey was funded within the framework of the Pafos Forest Management Plan (Pafos Forest Management Plan EEA Grant). We thank Takis Tsintidis (Forestry Department) for all assistance in Pafos and Troodos Forests. At HCMR in Athens we thank Sofia Giakoumi for expedition logistics and project management. Lastly we thank D.S. Zogaris who worked in the field during electrofishing in 2010.

\section{REFERENCES}

Abell R., Thieme M.L., Revenga C., Bryer M., Kottelat M., Bogutskaya N., Coad B., Mandrak N., ContrerasBalderas S., Bussing W., Stiassny M.L.J., Skelton P.,
Allen G.R., Unmack P., Naseka A., Ng R., Sindorf N., Robertson J., Armijo E., Higgins J.V., Heibel T.J., Wikramanayake E., Olson D., López H.L., Reis R.E., Lundberg J.G., Sabaj-Pérez M.H., Petry P. 2008. Freshwater ecoregions of the world: A new map of biogeographic units for freshwater biodiversity conservation. BioScience 58 (5): 403-414.

DOI: $10.1641 / \mathrm{B} 580507$

Adams S.B., Warren M.L.jr. 2005. Recolonization by warmwater fishes and crayfishes after severe drought in upper coastal plain hill streams. Transactions of the American Fisheries Society 134 (5): 1173-1192.

DOI: $10.1577 / \mathrm{T} 04-089.1$

Almada V.C., Robalo J.I., Levy A., Freyhof J., Bernardi G., Doadrio I. 2009. Phylogenetic analysis of PeriMediterranean blennies of the genus Salaria: Molecular insights on the colonization of freshwaters. Molecular Phylogenetics and Evolution 52 (2): 424-431.

DOI: 10.1016/j.ympev.2009.03.029

Anonymous 1998. Fishes of the Cyprus reservoirs: Angler's guide. Ministry of Agriculture, Natural Resources and Environment, Fisheries Department, Press and Information Office, Republic of Cyprus.

Anonymous 2000. Directive 2000/60/EC of the European Parliament and the Council of 23 October 2000 establishing a framework for Community action in the field of water policy. Official Journal of the European Communities 22.12.2000; EN: L 327/1.

Anonymous 2004. Manual for the application of the European Fish Index-EFI. A fish-based method to assess the ecological status of European rivers in support of the Water Framework Directive. FAME Consortium. Final Report, Version 1.1, January 2005.

Anonymous 2006. Strategic evaluation on environmental and risk prevention under structural and cohesion funds for the period 2007-2013. National Evaluation Report for Cyprus/ Directorate General Regional Policy. GHK. http//ec.europa.eu/regional_policy/sources/docgener/evalu ation/pdf/evalstrat_env/cy_main.pdf.

Baier F., Sparrow D.J., Wiedl H.-J. 2009. The amphibians and reptiles of Cyprus. Edition Chimaira, Frankfurt am Main, Germany.

Bath H. 2003. Salaria fluviatilis (Asso, 1784). Pp. 97-121. In: Miller P.J. (ed.) The freshwater fishes of Europe. Vol. 8/1. Mugilidae, Atherinidae, Atherinopsidae, Blenniidae, Odontobutidea, Gobiidae. AULA-Verlag, Wiesbaden, Germany.

Benejam L., Angermeier P.L., Munné A., García-Berthou E. 2010. Assessing effects of water abstraction on fish assemblages in Mediterranean streams. Freshwater Biology 55 (3): 628-642.

DOI: $10.1111 / \mathrm{j} .1365-2427.2009 .02299 . \mathrm{x}$

Bernez I., Haury J., Ferreira M.T. 2002. Downstream effects of a hydroelectric reservoir on aquatic plant assemblages. In: Proceedings of the 2nd Symposium on European Freshwater Systems. The Scientific World Journal 2: 740-750.

DOI: $10.1100 /$ tsw.2002.142

Bianco P.G., Ahnlet H., Economidis P.S. 1996. The freshwater fishes from eastern, and large Mediterranean islands with 
comments on their safety status. Acta Universitatis Carolinae. Biologica 40: 45-60.

Böhme W., Wiedl H. 1994. Status and zoogeography of the herpetofauna of Cyprus with taxonomic and natural history notes on selected species (Rana, Coluber, Natrix, Vipera). Zoology in the Middle East 10: 31-52.

Botkin D.B. 2001. The naturalness of biological invasions. Western North American Naturalist 61 (3): 261-266.

Chang M.-H., Lin Y.-S., Chaung L.-C. 1999. Effect of dams on fish assemblages of the Tachia River, Taiwan. Acta Zoologica Taiwanica 10 (2): 77-90.

Charalambidou I., Gücel S. 2009. Bibliographic index of flora, fauna, biodiversity, and nature conservation in Cyprus. Unit of Environmental Studies (Cyprus Center of European and International Affairs), UES-CCEIA/ESI/TCBA/GAG/, Nicosia, Cyprus.

Charalambidou I., Gücel S., Kassinis N., Turkseven N., Fuller W., Kuyucu A., Yorgancı H. 2008. Waterbirds in Cyprus 2007/08. Unit of Environmental Studies (Cyprus Center of European and International Affairs), UESCCEIA/TCBA/CGF, Nicosia, Cyprus.

Copp G.H., Bianco P.G., Bogutskaya N.G., Erős T., Falka I., Ferreira M.T., Fox M.G., Freyhof J., Gozlan R.E., Grabowska J., Kováč V., Moreno-Amich R., Naseka A.M., Peňáz M., Povž M., Przybylski M., Robillard M., Russell I.C., Stakẻnas S., Šumer S., Vila-Gispert A., Wiesner C. 2005. To be, or not to be, a non-native freshwater fish? Journal of Applied Ichthyology 21 (4): 242-262. DOI: $10.1111 /$ j.1439-0426.2005.00690.x

Côtė M., Vinyoles D., Reynolds J.D., Doadrio I., Perdices A. 1999. Potential impacts of gravel extraction on Spanish populations of river blennies Salaria fuviatilis (Pisces, Blenniidae). Biological Conservation 87 (3): 359-367. DOI: 10.1016/S0006-3207(98)00072-X

Davis A.J., Jenkinson L.S., Lawton J.L., Shorrocks B., Wood S. 1998. Making mistakes when predicting shifts in species range in response to global warming. Nature 391 (6669): 783-786.

DOI: $10.1038 / 35842$

deMaynadier P., Hunter M. 1997. The role of keystone ecosystems in landscapes. Pp. 68-76. In: Boyce M.S., Haney A. (eds.) Ecosystem management. Yale University Press, New Haven, CT, USA.

Elvira B. 2001. Identification of non-native freshwater fishes established in Europe and assessment of their potential threats to the biological diversity. Convention on the Conservation of European Wildlife and Natural Habitats, Standing Committee 21st Meeting, Strasbourg, 26-30 November 2001, Council of Europe, T-PVS (2001) 6.

Evans M.I. 1994. Important birds areas of the Middle East. Ornithological Society of the Middle East, International Waterfowl and Wetlands Research Bureau.

Ferreira T., Oliveira J., Caiola N., de Sostoa A., Casals F., Cortes R., Economou A.N., Zogaris S., Garcia-Jalon D., Ilhéu M., Martinez-Capel F., Pont D., Rogers C., Prenda J. 2007. Ecological traits of fish assemblages from Mediterranean Europe and their responses to human disturbance. Fisheries Management and Ecology 14 (6): 473-481. DOI: 10.1111/j.1365-2400.2007.00584.x
Freyhof J., Kottelat M. 2008. Anguilla anguilla, in IUCN. 2010 The IUCN Red List of threatened species, version 2010.1, www.iucnredlist.org (downloaded on 10 April 2010).

Froese R., Pauly D. (eds.) 2012. FishBase. [version 03/2012] http://www.fishbase.org.

Gherardi F., Böhme W. 2000. Are non-indigenous species "ecological malignancies"? Ethology Ecology and Evolution 12 (3): 326-328. DOI: $10.1080 / 08927014.2000 .9522805$

Godinho F.N., Ferreira M.T. 1998. The relative influence of exotic species and environmental factors on an Iberian native fish community. Environmental Biology of Fishes 51 (1): 41-51. DOI: $10.1023 / \mathrm{A}: 1007412714605$

Grove A.T., Rackham O. 2001. The nature of Mediterranean Europe: an ecological history. Yale University Press, New Haven, CT, USA.

Hadjisterikotis E., Masala B., Reese D.S. 2000. The origin and extinction of the large endemic Pleistocene mammals of Cyprus. Biogeographia 21: 593-606.

Henrichs T., Alcamo J. 2001. Europe's water stress today and in the future. In: Lehner B., Henrichs T., Döll P., Alcamo J. (eds.) EuroWasser; Model-based assessment of European water resources and hydrology in the face of global change. Kassel World Water Series No. 5, Kassel, Germany.

Herbold B., Moyle P.B. 1986. Introduced species and vacant niches. The American Naturalist 128 (5): 751-760.

Irz P., Odion M., Argillier C., Pont D. 2006. Comparison between the fish communities of lakes, reservoirs and rivers: Can natural systems help define the ecological potential of reservoirs? Aquatic Sciences 68 (1): 109-116. DOI: $10.1007 / \mathrm{s} 00027-005-0812-3$

Kassapis R.G. 2011. Oysters, pines and elephants (The story of Cyprus fossils). Heritage Publications. Nicosia, Cyprus.

Kottelat M., Freyhof J. 2007. Handbook of European freshwater fishes. Kottelat and Freyhof, Cornol, Switzerland, Berlin, Germany.

Laikre L. (ed.) 1999. Conservation genetic management of brown trout (Salmo trutta) in Europe. Report by the concerted action on identification, management and exploitation of genetic resources in brown trout (Salmo trutta) (,TROUTCONCERT"; EU FAIR CT97-3882).

Lever C. 1990. Naturalized fishes of the world. Academic Press, London.

Mathews W.J. 1998. Patterns in freshwater fish ecology. Chapman and Hall, New York.

Michaelides S., Pashiardis S. 2008. Monitoring drought in Cyprus during the 2007-2008 hydrometeorological year by using the Standard Precipitation Index (SPI). European Water 23/24: 123-131.

Moyle P.B., Light T. 1996. Fish invasions in California: do abiotic factors determine success? Ecology 77: 1666-1670.

Omorphos C., Socratous G., Ioannou E. (eds.) 2005. Dams of Cyprus. Ministry of Agriculture, Natural Resources and Environment, Water Developmenet Department, PIO Cyprus/Archontides Press.

Rackham O., Moody J. 1996. The making of the Cretan landscape. Manchester University Press, United Kingdom.

Reyes-Gavilán F.G., Garrido R., Nicieza A.G., Toledo M.M., Braña F. 1996. Fish community variation along physical 
gradients in short streams of northern Spain and the disruptive effect of dams. Hydrobiologia 321 (2): 155-163. DOI: $10.1007 / \mathrm{BF} 00023171$

Sabater S., Tockner K. 2010. Effects of hydrological alterations on the ecological quality of river ecosystems. Pp. 15-39. In: Sabater S., Barceló D. (eds.) Water scarcity in the Mediterranean; The handbook of environmental chemistry. Vol. 8. Perspectives under global change. SpringerVerlag, Heidelberg, Germany.

Schlaepfer M.A., Sax D.F., Olden J.D. 2011. The potential conservation value of non-native species. Conservation Biology 25 (3): 428-437. DOI: 10.1111/j.1523-1739.2010.01646.x.

Skoulikidis N.T., Vardakas L., Karaouzas I., Ekonomou A.N., Dimitriou E., Zogaris S. 2011. Assessing water stress in a Mediterranean lotic system: insights from an artificially intermittent river in Greece. Aquatic Sciences 73 (4): 581-597.

DOI: $10.1007 / \mathrm{s} 00027-011-0228-1$

Smith K.G., Darwall W.R.T. 2006. The status and distribution of Freshwater fish endemic to the Mediterranean basin. IUCN Red List of Threatened Species-Mediterranean Regional Assessment No. 1., IUCN, Gland, Switzerland and Cambridge, UK.

Stephanou D. 1988. Twenty years of experience in managing Cyprus reservoirs for angling. Pp. 1-13. In: Densen W.L.T., van Steinmetz B., Hughes R.H. (eds.). Management of freshwater fisheries: Proceedings of a symposium organized by the European Inland Fisheries Advisory Commission. 31 May-3 June 1988, Göteborg, Sweden.

Thirgood J.V. 1987. Cyprus: a chronicle of its forests, land and people. University of British Columbia Press, Vancouver, Canada.

Tourenq C., Shuriqi M.K. 2010. Artificial wetland biodiversity in desert countries, example of the Wadi Ham Dam in Fujairah Emirate, UAE-A call for a proper national monitoring of UAE wetlands and waterbirds. Wildlife Middle East News 4 (4): [no page numbers].

Van Neer W., Lernau O., Friedman R., Mumford G., Poblome J., Waelkens M. 2004. Fish remains from archaeological sites as indicators of former trade connections in the Eastern Mediterranean. Paléorient 30 (1): 101-147.
Vandekerkhove J., Cardoso A.C. 2010. Alien species and the Water Framework Directive: Questionnaire results. European Commission Joint Research Centre Institute for Environment and Sustainability. DOI: 10.2788/64083.

Vila-Gispert A., García-Berthou E., Moreno-Amich R. 2002. Fish zonation in a Mediterranean stream: Effects of human disturbances. Aquatic Sciences 64 (2): 163-170.

DOI: $10.1007 / \mathrm{s} 00027-002-8064-\mathrm{y}$

Vinyoles D., Robalo J.I., de Sostoa A., Almodóvar A., Elvira B., Nicola G.G, Fernández-Delgado C., Santos C.S., Doadrio I., Sardà-Palomera F., Almada V.C. 2007. Spread of the alien bleak Alburnus alburnus (Linnaeus, 1758) (Actinopterygii, Cyprinidae) in the Iberian Peninsula: the role of reservoirs. Graellsia 63 (1): 101-110. DOI: 10.3989 /graellsia.2007.v63.i1.84

Welcomme R.L. 1988. International introductions of inland aquatic species. FAO Fisheries Technical Paper No. 294. Food and Agriculture Organization of the United Nations, Rome.

Zogaris S., Chatzinikolaou Y., Koutsikos N., Oikonomou E., Economou A.N., Giakoumi S., Ferreira M.T. 2011. Historical information and information on previous work done regarding fish in the rivers of Cyprus, and pre-selection of sampling sites. Hellenic Center for Marine Research / Instituto Superior de Agronomia, Universidade Técnica de Lisboa. Unpublished Report; Contract No. TAY 49/2010. Water Development Department, Republic of Cyprus.

Zogaris S., Economou A., Dimopoulos P. 2009. Ecoregions in the southern Balkans: Should their boundaries be revised? Environmental Management 43 (4): 682-697. DOI: $10.1007 / \mathrm{s} 00267-008-9243-y$

Received: 10 February 2012 Accepted: 1 July 2012 Published electronically: 30 September 2012 